\title{
Rancang Bangun Sistem Informasi Pengolahan Nilai Rapor Berbasis Web Pada SMK Negeri 1 Kotaraja
}

\author{
Desak Made Dwi Utami Putra*1, ${ }^{1}$ Mohamad Ariansidi ${ }^{2}$ \\ ${ }^{1,2}$ Program Studi Teknik Informatika, STMIK STIKOM Indonesia, Bali \\ e-mail: *11 desak.utami@ stiki-indonesia.ac.id, ${ }^{2}$ imohamad.ariansidi@ gmail.com
}

\begin{abstract}
Abstrak
Penilaian merupakan bentuk evaluasi terhadap siswa atau peserta didik, hasil akhir dari suatu capaian belajar. Penilaian akhir di SMK Negeri 1 Kotaraja berbentuk rapor atau yang sekarang lebih dikenal dengan lembar hasil belajar siswa. Proses perekapan nilai pada SMK Negeri 1 Kotaraja masih menggunakan cara konvensional dalam pengolahan nilai yaitu, dengan mengandalkan formulir data nilai siswa yang diberikan oleh guru mata pelajaran yang masih ada kemungkinan formulir tersebut hilang, terselip, dan tercecer. Selain itu cara tersebut rentan terjadi kesalahan dan tentunya akan merepotkan disebabkan oleh beberapa hal: ketentuan dalam penghitungan nilai cukup rumit karena ada beberapa nilai seperti nilai ulangan harian dan nilai tugas yang nilainya dihitung lebih dari satu kali pada setiap rata-rata nilainya. Langkah-langkah yang digunakan untuk pengolahan nilai tidak sederhana, memakan waktu rata-rata sampai 7 hari untuk mengolahnya, sehingga sering kali berdampak pada pembagian rapor menjadi terlambat. Dari permasalahan diatas maka dibangun sistem informasi pengolahan nilai rapor berbasis web yang dapat dimanfaatkan oleh SMK Negeri 1 Kotaraja untuk mempermudah guru melakukan proses pengolahan nilai secara efektif dan efisien. Hasil pengujian black-box testing yang telah dilakukan menyatakan bahwa fitur pada sistem informasi pengolahan nilai rapor ini telah mampu mengelola nilai rapor siswa sehingga dapat membantu kinerja guru dan mempermudah siswa mengakses rapor secara online.
\end{abstract}

Kata kunci-Sistem Informasi Pengolahan Nilai, Rapor, Web.

\begin{abstract}
Assessment is the technique of evaluating students as the result of a learning achievement. Final assessment at SMK Negeri 1 Kotaraja is a report or student's learning outcomes sheets. The process of calculating values at SMK Negeri 1 Kotaraja has been used still the conventional method process by using a list of score that given by teachers that have the possibility lost, tucked, and scattered. Even it will easily human error and quite complicated because there are many scores that have to calculated, such as daily test scores and assignment scores that have to be calculated each average score, steps used are very complicated so it takes about 7 days to process its, That is why the distribution of report cards to the students becomes delayed. Based on the problem above, it is aimed to create an information system of scoring processing report on web based that could helped teacher of SMK Negeri 1 Kotaraja in more effective and efficient processed. The results of blackbox testing that has been done stated that information system of scoring processing report that helped could teacher performance and help students esier in accessing online report.
\end{abstract}

Keywords - Value Processing Information System, Report Card, Web 


\section{PENDAHULUAN}

Sekolah merupakan lembaga untuk belajar dan mengajar serta tempat menerima dan memberi pelajaran. Secara umum sekolah adalah lembaga pendidikan yang didirikan oleh negara juga swasta yang dirancang untuk mengajari, mengelola dan mendidik siswa atau peserta didik melalui bimbingan yang diberikan oleh tenaga pendidik. Untuk menjadi sebuah sekolah, ada beberapa sarana dan prasarana yang harus disediakan seperti ruang belajar, perpustakaan, gedung, laboratorium, dan lain sebagainya. Proses pembelajaran dalam proses belajar, mulai dari proses belajar-mengajar hingga belajar Hasil akhir dari pembelajaran siswa atau peserta didik.

Proses Pembelajaran-Mengajar (PBM) atau Kegiatan Belajar-Mengajar (KBM) dalam suatu proses pendidikan, mulai dari tingkat dasar dan perguruan tinggi. Khusus untuk tingkat dasar sampai menengah atas, hasil akhir dari sebagian besar rapor atau yang sekarang lebih dikenal dengan lembar belajar siswa atau peserta didik, sesuai dengan penilaian terhadap siswa atau peserta didik dalam lembaga pendidikan seperti di SMK Negeri 1 Kotaraja.

SMK Negeri 1 Kotaraja merupakan lembaga penyelenggara pendidikan yang berdiri pada tanggal 1 Juli 2011 dengan jumlah siswa pertama yaitu 41 orang. Pada saat itu hanya disediakan 2 (dua) kompetensi keahlian yaitu Administrasi Perkantoran dan Agribisnis Tanaman Pangan dan Hortikultura. Dengan visi "Menjadikan SMK Negeri 1 Kotaraja sebagai Lembaga Pendidikan yang Menghasilkan Sumber Daya Manusia (SDM) Berkarakter, Kompeten, Profesional, Produktif, dan Kompetitif dalam Era Globalisasi”. Sekolah ini memiliki 10 (sepuluh) kompetensi keahlian Agribisnis Tanaman Pangan dan Hortikultura, Teknologi Pangan dan Hasil Pertanian, perhotelan, Teknik Kendaraan Ringan, Teknik Sepeda Motor, Teknik Komputer dan Jaringan, Administrasi Perkantoran, Usaha Perjalanan Wisata, ATU, dan ATP. Tercatat saat ini di SMK Negeri 1 Kotaraja memiliki 712 murid pada semua kompetensi keahlian.

Berdasarkan jumlah siswa tersebut, diperlukan sistem penyajian nilai yang cepat dan mudah, namun berdasarkan hasil wawancara dengan Bapak Insan Karisma S.Pd., selaku Wakasek Kurikulum SMK Negeri 1 Kotaraja. Pengolahan nilai pada SMK Negeri 1 Kotaraja masih bersifat manual. Hasil Nilai pada SMK Negeri 1 Kotaraja ini merupakan nilai akademik yang dikeluarkan pada buku laporan belajar siswa atau rapor setiap semester. Buku rapor diberikan kepada siswa wali oleh pihak penyelenggara tempat belajar-mengajar diadakan. Berikut adalah tahapan proses pengolahan nilai rapor siswa. Pertama, guru dapat membaca nilai siswa dalam bentuk Nilai yang sudah dikelompokan masing-masing kelas. Tahap kedua, guru pengampu mata menyampaikan nilai kepada wali kelas untuk melakukan perekapan berdasarkan nilai-nilai yang sudah dikumpulkan guru pengampu masing-masing mata pelajaran. Tahap tiga, jika perekapan telah selesai, wali kelas akan memberikan rekapan nilai ke bagian yang dikembalikan untuk nilai rapor. Tahap Empat, jika rapor sudah dicetak maka akan dikirim ke kelas wali untuk divalidasi (tanda tangan) oleh kepala sekolah. Tahap penilaian, setelah divalidasi kepala sekolah nilai rapor akan dibuatkan arsip dalam bentuk nilai lajer. Tahap keenam, rapor akan dibagikan kepada orang tua wali atau siswa pada saat penyerahan rapor. Oleh karena itu, pihak sekolah kesulitan dalam pengelolaan nilai, Pengelolahan sudah terorganisir tetapi masih belum optimal, memiliki struktur yang hampir mirip dengan penelitian [1].

Berdasarkan hasil wawancara atas dapat disimpulkan bahwa SMK Negeri 1 Kotaraja masih menggunakan cara konvensional dalam pengolahan nilai, dengan cara tersebut rentan terhadap masalah, memerlukan banyak waktu dan tenaga dalam melakukan pengolahan nilai, diharapkan akan merepotkan disebabkan oleh hal hal terkait lainnya rumit karena ada beberapa nilai input seperti nilai ulangan harian dan nilai tugas yang input nilainya lebih dari satu kali dan dihitung nilai-rata nilainya, sehingga dalam satu sekolah memiliki menghitung siswa dan

JSIKTI Vol. 2, No. 2, Desember 2019: $53-64$ 
masing-masing memiliki nilai yang berbeda sesuai dengan perbincangan Proses Memproses nilai rapor membutuhkan waktu kurang lebih hingga 2 minggu. Permasalahan lain yang terjadi, beberapa guru pengampu mata pelajaran ada yang mengumpulkan nilai melewati batas yang telah ditentukan, jadi jika ada guru yang terlambat mengumpulkan nilai siswa maka proses perekapan dan penyerahan rapor akan terlambat. Untuk mengatasi masalah yang dialami SMK Negeri 1 Kotaraja diperlukan pembenahan terhadap sistem yang sedang berjalan dan pengembangannya harus disesuaikan dengan kebutuhan saat ini yaitu sistem informasi yang digunakan untuk pengolahan nilai rapor siswa, sehingga proses pengolahan nilai rapor siswa menjadi lebih cepat [2].

\section{METODE PENELITIAN}

\section{1. State of the art}

Dasar-dasar Sebagai bahan pertimbangan dalam penelitian ini, telah dicantumkan 2 (dua) hasil penelitian terdahulu tentang sistem pengolahan nilai dari penulis yang berbeda, diantaranya :

Penelitian yang berjudul "Pembangunan Sistem Informasi Pengolahan Data Nilai Siswa Berbasis Web Pada Sekolah Menengah Kejuruan (SMK) Miftahul Huda Ngadirojo"[3]. Permasalahan yang terjadi yaitu pengolahan nilai raport di SMK Miftahul Huda Ngadirojo masih manual dan menggunakan bantuan Microsoft Excel. Hal ini membuat proses pengolahan nilai rapor menjadi lebih lama karena peng-input-an nilai rapor hanya dilakukan oleh wali kelas yang mengandalkan formulir data nilai siswa yang diberikan oleh guru mata pelajaran yang masih ada kemingkinanan formulir tersebut hilang, terselip, dan tercecer. Maka penelitian ini bertujuan untuk memberikan kemudahan dalam pengolahan data siswa, data guru, data kelas, data mata pelajaran, dan data nilai rapor siswa.

Penelitiaan sebelumnya yang serupa dengan topik ini juga yang berjudul "Aplikasi Pengolah Nilai Peserta Didik Pada SDIT Nur Hasan Senting Berbasis Desktop" menggunakan Visual BasicNET [4]. Permasalahan yang terjadi adalah pengolahan nilai yang masih menggunakan menggunakan cara konvensional yang rentan terjadi kesalahan, memakan banyak waktu serta tenaga dan ketentuan dalam penghitungan nilai cukup rumit karena ada beberapa input nilai seperti nilai ulangan harian dan nilai tugas yang input nilainya lebih dari satu kali dan dihitung rata-rata nilainya. Maka dibuatkanlah aplikasi desktop pengolahan nilai rapor untuk memproses nilai peserta didik yaitu nilai ulangan harian, tugas, ujian tengah semester dan ujian akhir semester, agar memberikan kemudahan kepada guru dalam mengelola dan penyajian data nilai siswa secara cepat.

Dari kedua penelitian di atas penulis akan mengembangkan, merancang, dan membangun Sistem Informasi Pengolahan Nilai Rapor Berbasis Web Pada SMK Negeri 1 Kotaraja dengan menggabungkan kedua penelitian terdahulu. Perbedaan dari penelitian terdahulu di atas adalah objek penelitian berfokus pada SMK Negeri 1 Kotaraja, pokok pembahasan dalam penelitian ini yaitu berkaitan dengan pengolahan data user, data guru, data siswa, data kelas, data mata pelajaran, data jurusan, data kelas siswa, data tahun ajaran, data guru pengajar, data ekstrakulikuler, data nilai siswa.

Pengembangan penelitian ini juga mampu memberikan informasi cetak nilai rapor untuk memugkinkan siswa mencetak mandiri rapor, serta notifikasi dan setup tanggal input nilai untuk mengingatkan masing-masing guru pengampu mata pelajaran agar mengumpulkan nilai sesuai dengan waktu yang telah ditentukan dan menampilkan nilai rata-rata setiap mata pelajaran untuk mengetahui pencapaian nilai siswa sehingga kepala sekolah dapat melakukan evaluasi metode pembelajaran sesuai dengan kebutuhan siswa. 


\subsection{Metode Penelitian}

Tempat dilakukan penelitian ini adalah SMK Negeri 1 Kotaraja yang beralamat di Jalan Pariwisata, Kotaraja - Tetebatu Kec. Sikur, Kab. Lombok Timur, Provinsi Nusa Tenggara Barat. Waktu yang dibutuhkan untuk penelitian ini mulai dari 3 Desember 2018 sampai dengan 3 Mei 2019. Pada Gambar 1 dan 2 berikut ini merupakan foto hasil dokumentasi pada SMK Negeri 1 Kotaraja dan Denah Lokasi SMK Negeri 1 Kotaraja.

Metode yang dipakai dalam pengumpulan dan pendukung penelitian ini yaitu dengan metodelogi pengembangan perangkat lunak waterfall dengan melakukan observasi, wawancara, dokumentasi, dan kepustakaan. Penelitian ini berawal dari tahap mengidentifikasi masalah, kemudian mengumpulkan data dan mengelolanya. Tahap berikutnya adalah menganalisis sistem dan merancang sistem. Selanjutnya melakukan implementasi berdasarkan rancangan dari sistem yang dibuat. Setelah sistem dibuat maka akan dilakukan pengujian sistem. Tahapan dari penelitian ini dapat dilihat pada Gambar 1.

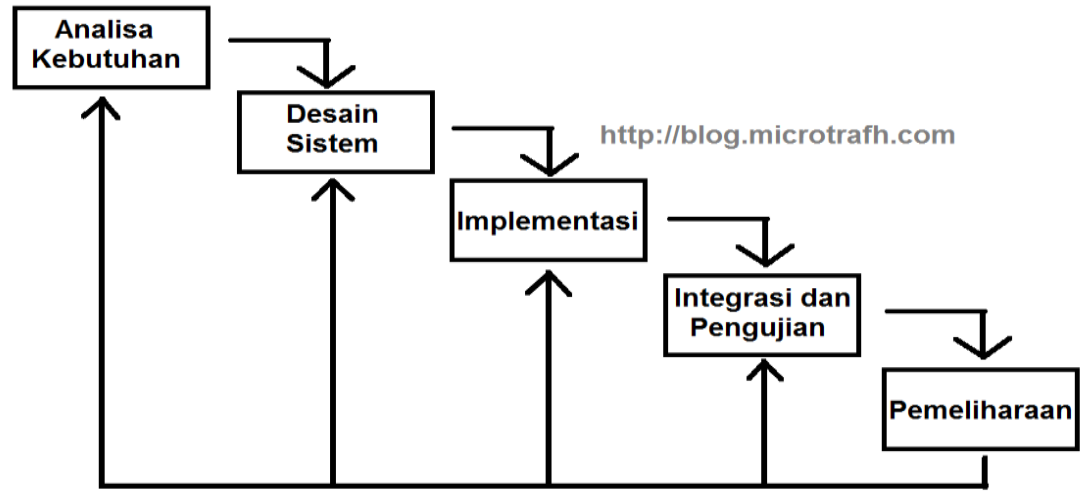

Gambar 1 Waterfall Model

\section{2 Metode Pengumpulan Data Primer}

Dalam sebuah penelitian ilmiah dibutuhkan teknik pengumpulan data agar data yang diolah menjadi informasi yang baik dan sesuai dengan yang sedang terjadi, maka digunakan beberapa metode pengumpulan data. Metode pengumpulan data yang digunakan pada penelitian ini yaitu metode pengumpulan data primer dan metode pengumpulan data skunder.

\subsubsection{Metode Pengumpulan Data Primer}

Metode pengumpulan data primer merupakan metode pengumpulan data yang diperoleh secara langsung dari sumbernya yang berhubungan dengan sistem pengolahan nilai rapor pada SMK Negeri 1 Kotaraja, ada dua metode pengumpulan data primer saat ini dipakai oleh penulis dalam melakukan penelitian ini, metode tersebut antara lain:

1. Metode Observasi

Metode Observasi merupakan salah satu metode yang digunakan untuk pengumpulan data, yang dilakukan dengan mengamati secara langsung mengenai objek yang akan diteliti. Dalam metode observasi, penulis melakukan pengamatan secara langsung dengan meninjau ke lokasi SMK Negeri 1 Kotaraja, untuk mengamati bagaimana alur dan proses pengolahan nilai rapor yang sedang berjalan pada SMK Negeri 1 Kotaraja.

2. Metode Wawancara

Metode wawancara dilakukan dengan cara komunikasi langsung dengan individu atau narasumber. Dengan melakukan wawancara, data yang didapat sangat bisa dipertanggungjawabkan dan valid. Wawancara dilakukan dengan narasumber yaitu Bapak Insan Karisma, S.Pd. sebagai Wakasek Kurukulum. Hasil wawancara didapatkan data mengenai prosedur-prosedur, sistem penilaian siswa sampai penyampaian hasil nilai siswa. Dari hasil wawancara penulis menyimpulkan, Bapak Insan Karisma meminta agar adanya sebuah sistem yang mempermudah untuk pengumpulan nilai

JSIKTI Vol. 2, No. 2, Desember 2019: $53-64$ 
semester dari masing-masing guru pengajar ke masing-masing wali kelas dan dapat mempermudah pengolahan nilai rapor pada SMK Negeri 1 Kotaraja.

\subsubsection{Metode Pengumpulan Data Skunder}

Metode pengumpulan data skunder adalah data yang diperoleh dari referensi buku-buku atau data browsing internet dengan melihat jurnal-jurnal atau juga website resmi.

1. Metode Kepustakaan

Metode kepustakan mendukung dan memperkuat landasan teori pada penelitian ini. Studi ini dilakukan dengan mengumpulkan data dari berbagai sumber buku, jurnal, dan literature pendukung untuk melengkapi teori-teori yang dibutuhkan dalam penelitian ini. Teori-teori yang mendukung penelitian ini antara lain jurnal Pengolahan Nilai Rapor, Pengantar Perancangan Sistem, Pengenalan Sistem Informasi.

2. Metode Dokumentasi

Dokumentasi merupakan salah satu teknik mengumpulkan data. Untuk teknik pengumpulan data dokumentasi penulis memperoleh beberapa gambar yang sudah disediakan oleh SMK Negeri 1 Kotaraja, yaitu berupa gambar form nilai dan gambar nilai rapor siswa hasil dokumentasi.

\subsection{Analisa dan Perancangan}

Analisis sistem ialah sebuah metode untuk mencari solusi dari permasalahan sistem yang ada dengan cara mengelompokkan komponen yang ada menjadi komponen-komponen yang lebih kecil agar solusi yang ditemukan sesuai dengan kebutuhan sistem [5]. Kegiatan analisis sistem adalah kegiatan untuk melihat sistem yang sudah berjalan [6], melihat bagian mana yang bagus dan tidak bagus kemudian mendokumentasikan kebutuhan yang akan dipenuhi dalam sistem yang baru.

\subsubsection{Statement Of Purpose (SOP)}

Statement Of Purpose (SOP) merupakan model yang berisi deskripsi tekstual sistem. Hal ini berguna bagi hampir semua level antara lain level puncak, level pemakai dan level lain yang tidak terlihat secara langsung dalam pengembangan sistem [7]. SOP hanya terdiri dari satu, dua atau lebih kalimat. Tetapi sebaliknya tidak lebih dari suatu paragraf, karena tidak digunakan untuk mendeskripsikan sistem secara detail.

\subsubsection{Event List (EL)}

Event List merupakan suatu daftar kejadian yang berasal dari luar sistem yang menyebabkan sistem melakukan respon terhadap kejadian-kejadian tersebut. Event List (EL) dapat dikatakan sebagai stimunisasi yang menggerakan sistem [6].

Daftar kejadian digambarkan dalam bentuk kalimat sederhana dan berfungsi untuk memodelkan kejadian yang terjadi dalam lingkungan sehari-hari dan membutuhkan tanggapan atau respon dari sistem [8]. Suatu kejadiaan mewakili satu aliran atau proses dalam diagram konteks serta diskripsi penyimpanan yang digunakan untuk memodelkan data harus diperhatikan dalam kaitannya dengan daftar kejadian.

\subsubsection{Database (Basis Data)}

Database adalah struktur penyimpanan data. Untuk menambah, mengakses dan memproses data yang disimpan dalam sebuah database komputer, diperlukan sistem manajemen database seperti MySq1 Server [9].

Database adalah sekumpulan tabel-tabel yang berisi data dan merupakan kumpulan dari field atau kolom [10]. Struktur file yang menyusun sebuah database adalah data record dan field yang saling berhubungan satu dengan yang lainnya, tersimpan dalam perangkat keras komputer dan digunakan perangkat lunak untuk memanipulasinya. Perangkat lunak yang digunakan untuk mengelola dan memanggil query basis data disebut Database Management System (DBMS).

Database Management System (DBMS) merupakan suatu perangkat lunak yang memungkinkan pengguna untuk mendefinisikan, merancang, memelihara, dan menentukan 
akses kontrol kedalam database. Beberapa fasilitas yang disediakan oleh Database Management System (DBMS), antara lain:

1. Database Management System (DBMS) memungkinkan pengguna untuk medefinisikan database melalui Data Definition Language (DDL). Data Definition Language (DDL) menydiakan fasilitas kepada pengguna untuk menentukan tipe data, struktur serta bataran aturan (constraint) pada data yang akan disimpan ke dalam database.

2. Database Management System (DBMS) memungkinkan pengguna membuat, mengubah, menghapus, dan menampilkan data dari database dengan menggunakan Data Manipulation Language (DML).

3. Database Management System (DBMS) menyediakan akses kontrol ke database, yaitu sebagai berikut.

4. Security System, yaitu sistem yang dapat mencegah pengguna yang tidak memiliki otoritas untuk mengakses database.

5. Integrity System, yaitu sistem yang menjaga konsistensi penyimpanan data.

6. Concurrency Control System, yaitu sistem yang memungkinkan pengguna untuk mengakses database bersamaan dengan pengguna lain.

7. Recovery Control System, yaitu mengembalikan database ke kondisi sebelumnya bila terjadi kerusakan atau kesalahan pada perangkat keras atau perangkat lunak.

8. Use-Accessible Catalog, yaitu adanya deskripsi data didalam sebuah database.

\subsubsection{Context Diagram $(C D)$}

Diagram konteks adalah diagram yang menggambarkan sumber serta tujuan data yang akan diproses atau dengan kata lain diagram tersebut digunakan untuk menggambarkan sistem secara umum/global dari keseluruhan sistem yang ada [10]. Diagram konteks menggambarkan sistem secara umum atau global. Diagram konteks menyoroti jumlah karakteristik sistem antara lain :

1. Kelompok pemakai, organisasi atau suatu sistem lain dimana sistem melakukan komunikasi (sebagai terminator).

2. Data masuk, yaitu data yang diterima sistem dari lingkungan dan harus diproses dengan cara tertentu.

3. Data keluar, yaitu data yang dihasilkan sistem dan diberikan ke dunia luar.

4. Penyimpanan data, yaitu digunakan secara bersamaan antara sistem dengan terminator. Hal ini berarti pembuatan simbol tersebut merupakan bagian dari luar sistem.

5. Batasan antara sistem dan lingkungan. Simbol yang digunakan dalam diagram konteks antara lain

6. Persegi panjang, untuk berkomunikasi langsung dengan sistem melalui aliran data.

7. Lingkaran, untuk menunjukan adanya kegiatan proses dalam sistem.

\subsubsection{Data Flow Diagram (DFD)}

Data Flow Diagram digunakan untuk menggambarkan suatu sistem yang telah ada atau sistem baru yang akan dikembangkan secara logika tanpa mempertimbangkan lingkungan fisik dimana data tersebut akan disimpan [11]. Data Flow Diagram juga digunakan untuk menggambarkan sistem sebagai susunan proses yang akan dihubungkan satu sama lain dengan alur data, baik secara manual maupun terkomputasi.

Adapun penjelasan mengenai simbol-simbol yang digunakan pada Data Flow Diagram, yaitu :

1. Entitas Luar (External Entity)

Merupakan kesatuan (entity) diluar lingkungan sistem yang dapat berupa orang, organisasi atau sistem lainnya yang berada lingkungan luarnya yang akan memberikan masukan (input) atau menerima keluaran (output) dan dari sistem kesatuan luar dapat disimbolkan dengan notasi kotak.

2. Proses (Process)।

Suatu proses adalah kegiatan atau kerja yang dilakukan oleh orang, mesin atau komputer dari hasil atau suatu arus data yang masuk ke dalam proses untuk dihasilkan 
arus data yang akan keluar dari proses. Simbol yang digunakan untuk proses ini adalah lingkaran, dimana aliran data yang masuk dan ditransformasikan ke aliran data keluar.

3. Arus Data (Data Flow)

Menunjukan arus dari data yang dapat berupa masukan untuk sistem atau hasil dari proses. Disimbolkan dengan satu panah yang mengalir diantara proses, simpanan data (data store), dan kesatuan luar (external entity).

4. Penyimpanan Data (Data Store)

Suatu simpanan dari data yang dapat berupa suatu file atau arsip. Dapat disimbolkan dengan sepasang garis horizontal pararel. Keuntungannya supaya mempermudah pemakai (user) yang kurang menguasai bidang komputer. Untuk lebih mengerti sistem yang akan dikembangkan/dikerjakan.

Tahapan-tahapan perancangan dengan menggunakan data flow diagram [12] :

1. Membuat DFD Level 0 atau Context Diagram

DFD level 0 menggambarkan sistem yang akan dibuat sebagai suatu entitas tunggal yang berinteraksi dengan orang manapun sistem lain. DFD level 0 digunakan untuk menggambarkan interaksi antara sistem yang akan dikembangkan dengan entitas luar.

2. Membuat DFD Level 1

DFD level 1 digunakan untuk menggambarkan modul-moduk yang ada didalam sistem yang akan dikembangkan. DFD level 1 merupakan hasil breakdown DFD level 0 yang sudah dibuat sebelumnya.

\section{HASIL DAN PEMBAHASAN}

\subsection{Analisis Kebutuhan Sistem}

Langakah awal dalam analisis sistem yang dilakukan adalah dengan mengetahui kebutuhan sistem. Tahap analisis akan dilakukan untuk mengumpulkan data yang telah dipelajari sebelumnya. Analisa yang dilakukan dalam penelitian ini berdasarkan pengamatan atau kajian saat proses pengolahan nilai rapor yang berjalan di SMK Negeri 1 Kotaraja. Tahap ini juga bertujuan untuk mengetahui kebutuhan sistem yang akan dibangun.

\subsubsection{Analisis Kebutuhan Fungsional}

Berikut ini adalah analisis kebutuhan fungsional dari sistem pengolahan nilai rapor yang akan dibangun yaitu:

1. Sistem dapat melakukan pengolahan nilai rapor

2. Memiliki fungsi keamanan untuk memproteksi atau melindungi sistem yaitu melalui proses login untuk pengguna. Dengan menginputkan username dan password (kata sandi) berdasarkan hak akses pengguna.

3. Sistem dapat mengelola data master siswa, data user, data guru, data mata pelajaran, data kelas, data jurusan, dan data tahun ajaran.

4. Sistem dapat menampilkan laporan nilai rapor siswa.

5. Sistem dapat menampilkan laporan nilai terbaik siswa.

6. Sistem dapat menampilkan laporan nilai rata-rata dari setiap mata pelajaran.

\subsubsection{Analisa Kebutuhan Non Fungsional}

Analisis kebutuhan fungsional dari sistem informasi pengolahan nilai rapor yang akan digunakan penulis dalam merancang dan membangun sistem ini, antara lain:

1. Hardware (Perangkat Keras)

Dalan membangun sistem informasi pengolahan nilai rapor pada SMK Negeri 1

Kotarama, diperlukan bebrapa perankat keras yang berfungsi untuk pembangunan dan 
pengujian sistem ataupun perangkat keras. Perangkat tersebut antara lain: processor, memory, hardisk, LCD atau monitor.

2. Software (Perangkat Lunak)'

Agar kebutuhan hardware diatas dapat dapat beroperasi secara optimal, maka komputer tersebut harus memenuhi spesifikasi yang diperlukan dukungan dari perangkat lunak (software) sesuai dengan kebutuhan sistem agar program aplikasi ini dapat berjalan dengan baik. Software tersebut adalah MySql dan Xampp.

\subsection{Document Flow Diagram}

Penjabaran analisa Document Flow Diagram secara tertulis. System yang sedang berlangsung dalam proses pembuatan nilai rapor yang saat ini pada SMK Negeri 1 Kotaraja sebagai berikut: masing-masing guru mata pelajaran mengumpulkan niai yang didapat siswa, memasukan nilai ke dalam form penilaian pada daftar yang telah disediakan oleh sekolah, setelah itu form nilai tersebut diserahkan ke wali kelas, kemudian wali kelas memasukan nilai tersebut ke dalam program Microsoft Excel, nilai tersebut kemudian dihitung menggunakan rumus untuk mendapatkan nilai akhir dari semua mata pelajaran, selanjutnya direkap dalam bentuk lejer nilai. Setelah itu wali kelas membuat rapor siswa yang nantinya rapor tersebut akan diberikan kepada masing-masing siswa. Document Flow Digram pengolahan nilai rapor dapat dilihat pada Gambar 2.

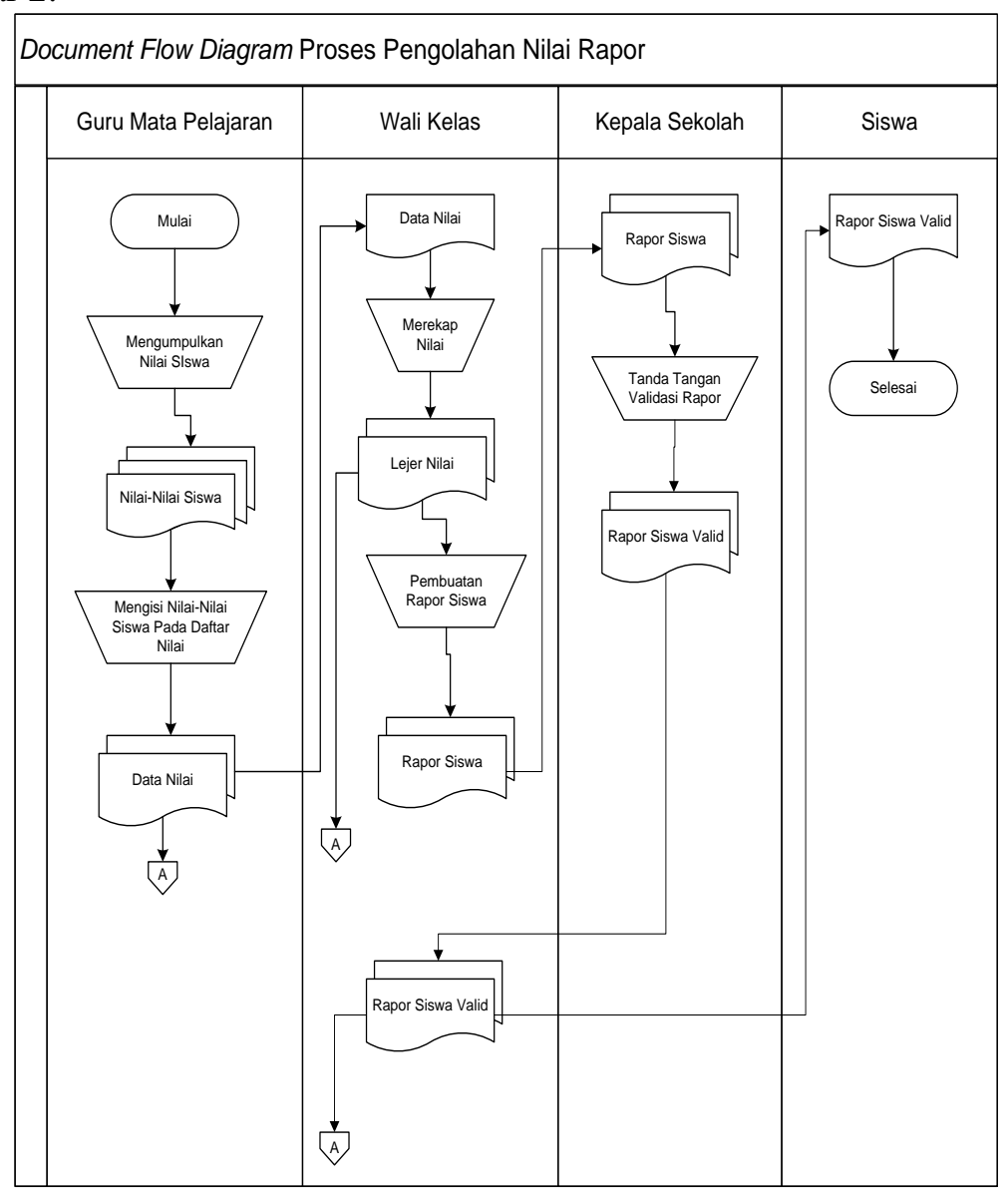

Gambar 2 Document Flow Diagram Pengolahan Nilai Rapor

\subsection{DFD Level 1 Mengelola Data Kelas Siswa}

Data Flow Diagram Level 1 mengelola data kelas siswa, menggambarkan proses yang terjadi pada data kelas siswa, alur sistem dan penyimpanan data. Data Flow Diagram Level 1 mengelola data kelas siswa memiliki 1 (satu) entitas yaitu admin dan terdapat 4 (empat) data sore yaitu siswa, jurusan, kelas, tahun ajaran dan guru. Dimana entitas admin dapat melakukan 3 
(tiga) proses yaitu tambah data kelas, ubah data kelas dan cari data kelas. DFD Level 1 mengelola data kelas siswa dapat dilihat pada Gambar 3

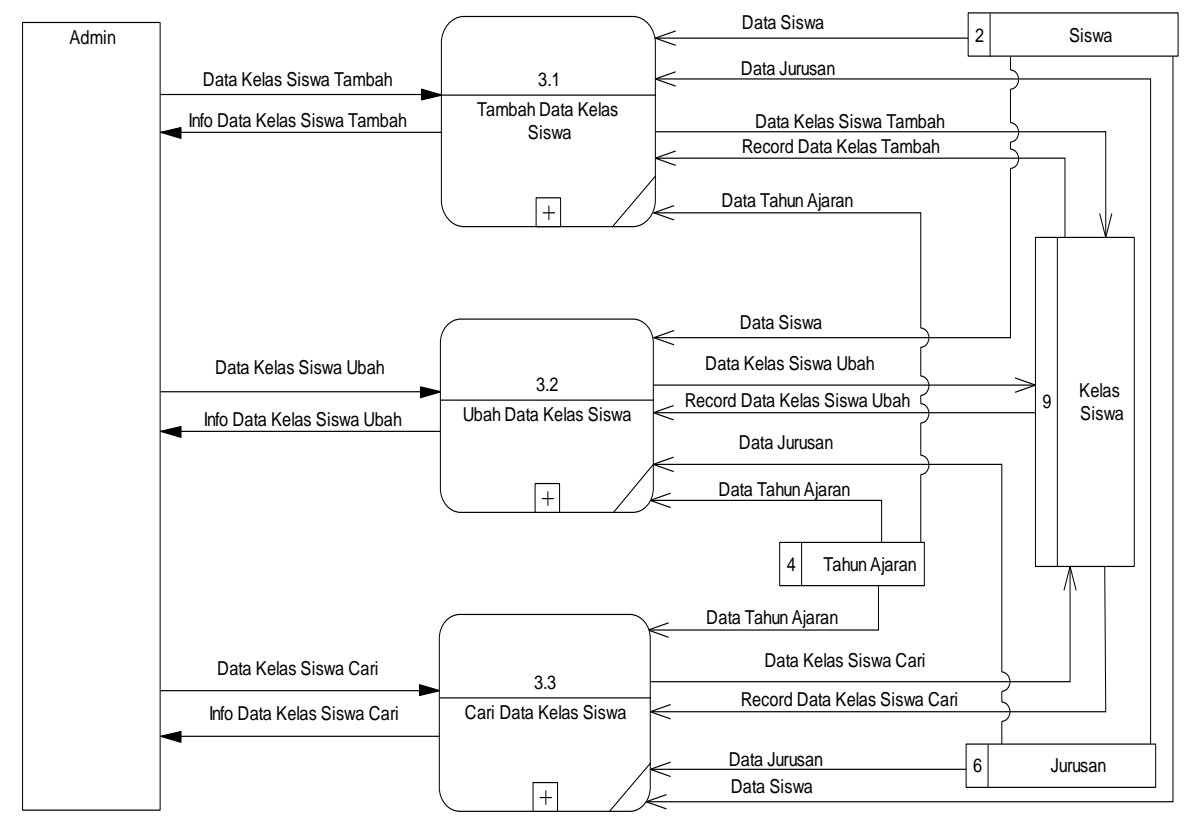

Gambar 3 DFD Level 1 Mengelola Data Kelas Siswa

Data Flow Diagram Level 1 mengelola data absensi, menggambarkan proses yang terjadi pada data absensi, alur sistem dan penyimpanan data. Data Flow Diagram Level 1 mengelola data absensi memiliki 1 (satu) entitas yaitu guru. Pada DFD Level 1 terdapat 3 (tiga) data sore yaitu kelas siswa, siswa, dan absensi. Dimana entitas guru dapat melakukan 3 (tiga) proses yaitu tambah data absensi, ubah data absensi dan cari data absensi. DFD Level 1 mengelola data absensi dapat dilihat pada Gambar 4.

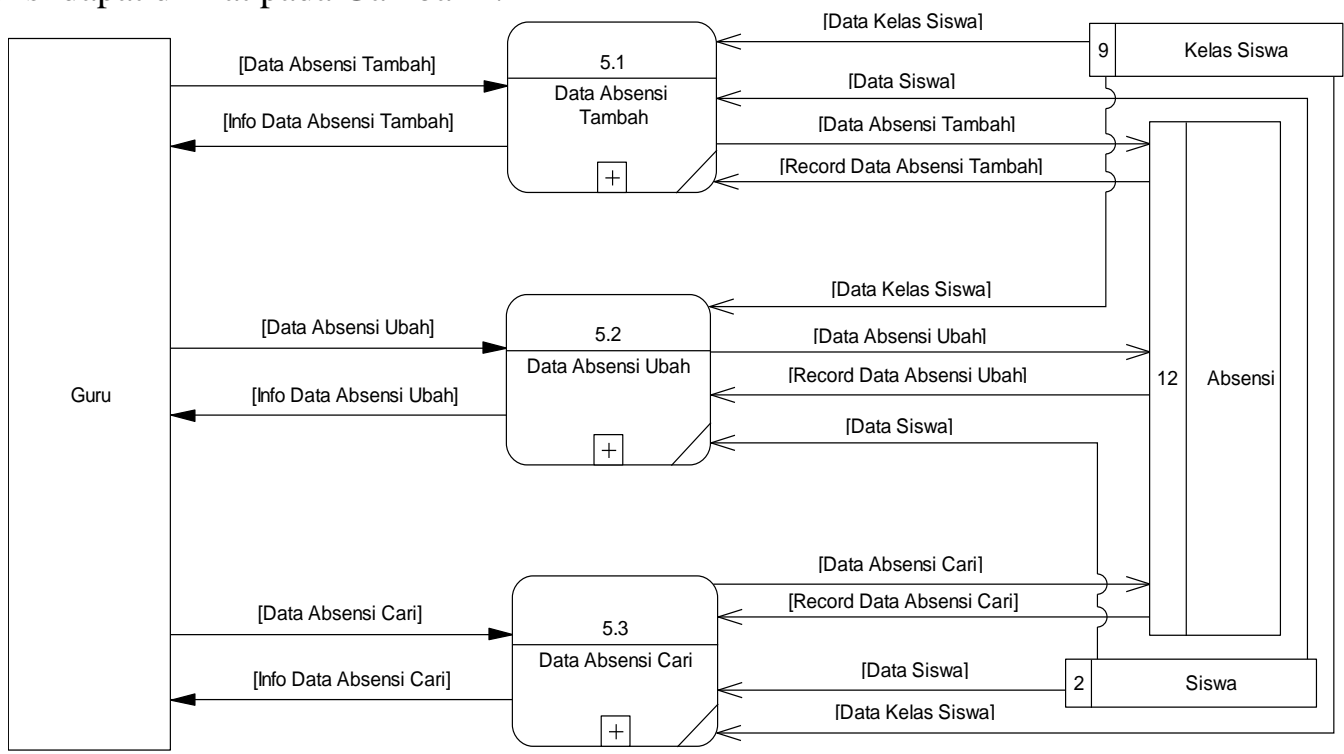

Gambar 4 DFD Level 1 Mengelola Data Absensi

\subsection{Antarmuka Pengguna (User Interface)}

Merancang antarmuka merupakan bagian penting dari merancang sistem. Berikut ini adalah perancangan user interface dari sistem informasi pengolahan nilai rapor pada SMK Negeri 1 Kotaraja. 
Rancangan Halaman Dashboard Admin, Halaman dashboard ini merupakan perancangan halaman utama admin setelah admin melakukan login. Pada perancangan halaman dashboard ini akan menampilkan grafik jumlah data siswa perangkatan dan tedapat beberapa menu yang dapat diakses yaitu data master, kelas siswa, guru pengajar, setup tanggal, mutasi kelas, dan laporan. Gambar rancangan halaman dashboard admin dapat dilihat pada Gambar 5.

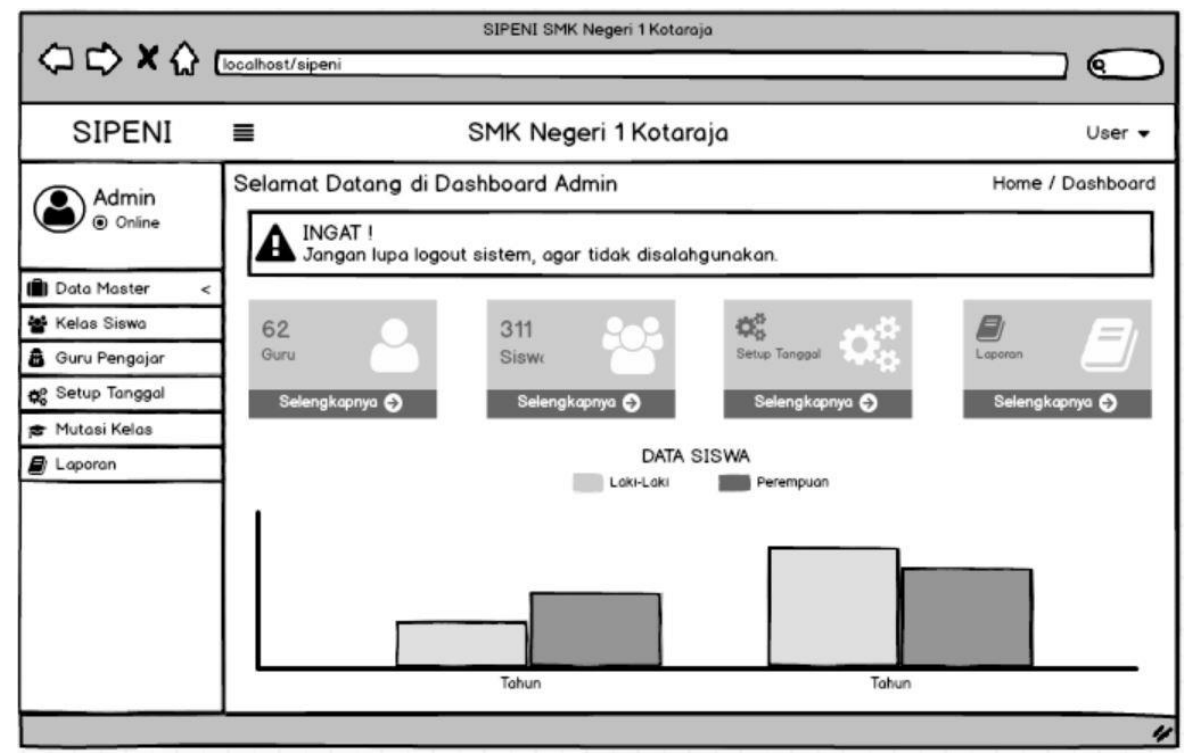

Gambar 5 Rancangan Halaman Dashboard Admin

Setelah melakukan analisis dan perancangan sistem, maka langkah selanjutnya yaitu implementasi sistem. Implementasi sistem akan mengubah bentuk dari analisis maupun perancangan menjadi bentuk bahasa pemrograman. Setelah implementasi, maka akan dilakukan pengujian terhadap sistem baru dan akan dilihat kekurangan-kekurangan pada aplikasinya untuk mengembangkan sistem selanjutnya.

1. Halaman Dashboard Admin

Halaman dashboard ini merupakan halaman utama admin setelah admin melakukan login. Pada halaman dashboard ini akan menampilkan grafik jumlah data siswa perangkatan dan tedapat beberapa menu yang dapat diakses yaitu data master, kelas siswa, guru pengajar, setup tanggal, mutasi kelas, dan laporan. Gambar halaman dashboard admin dapat dilihat pada Gambar 6.

2. Halaman Mengelola Data Siswa

Berikut ini merupakan halaman mengelola data siswa. Pada halaman ini digunakan admin untuk mengelola data siswa seperti menambah data siswa, mengubah data siswa, dan mencari data siswa. Halaman ini akan muncul jika admin memilih menu data siswa. Pada halaman ini terdapat searchbox untuk mencari data siswa, terdapat juga kolom aksi ubah data siswa untuk masuk kehalaman ubah data siswa, dan button tambah untuk menambah data siswa. Rancangan halaman data siswa dapat dilihat pada Gambar 7.

JSIKTI Vol. 2, No. 2, Desember 2019: $53-64$ 


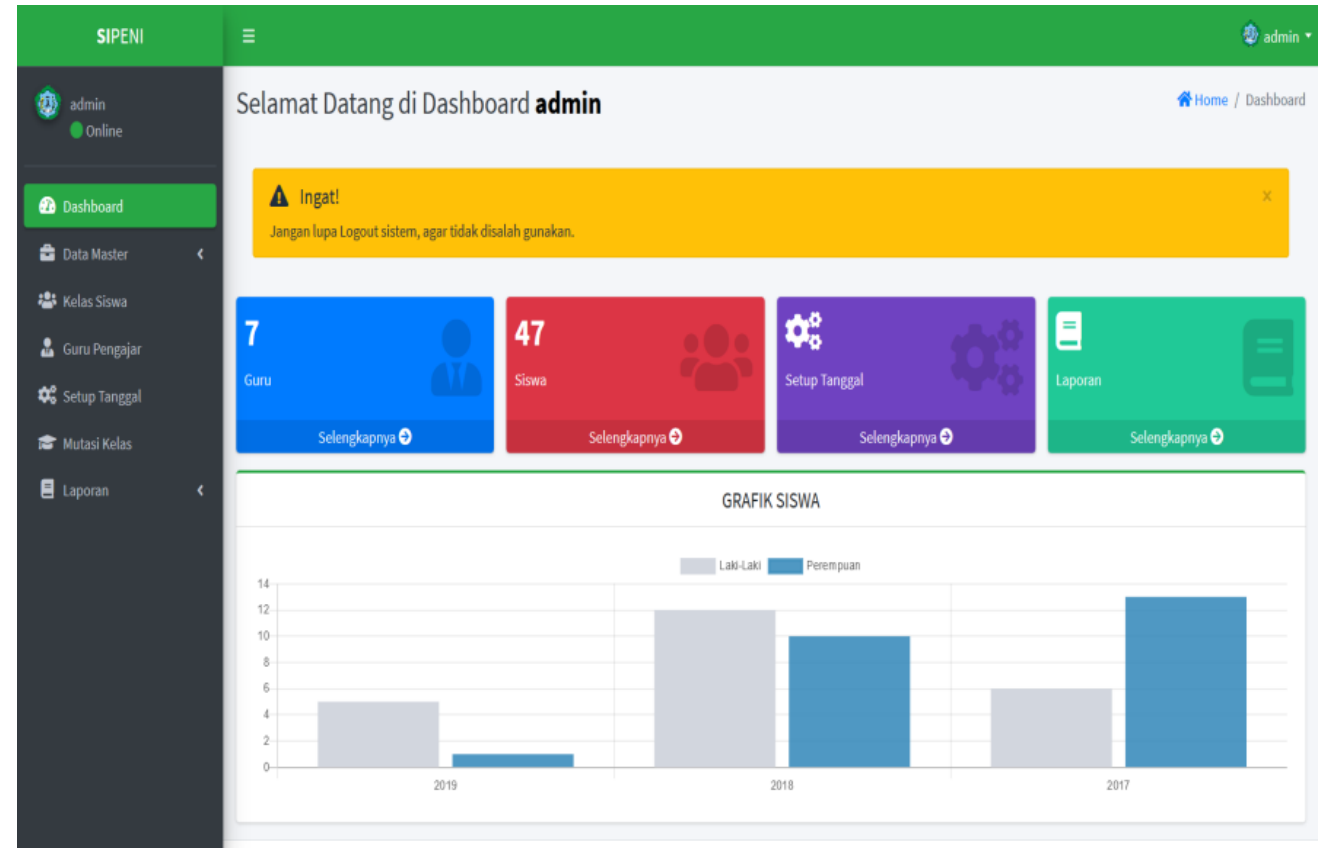

Gambar 6 Tampilan Halaman Dashboard Admin

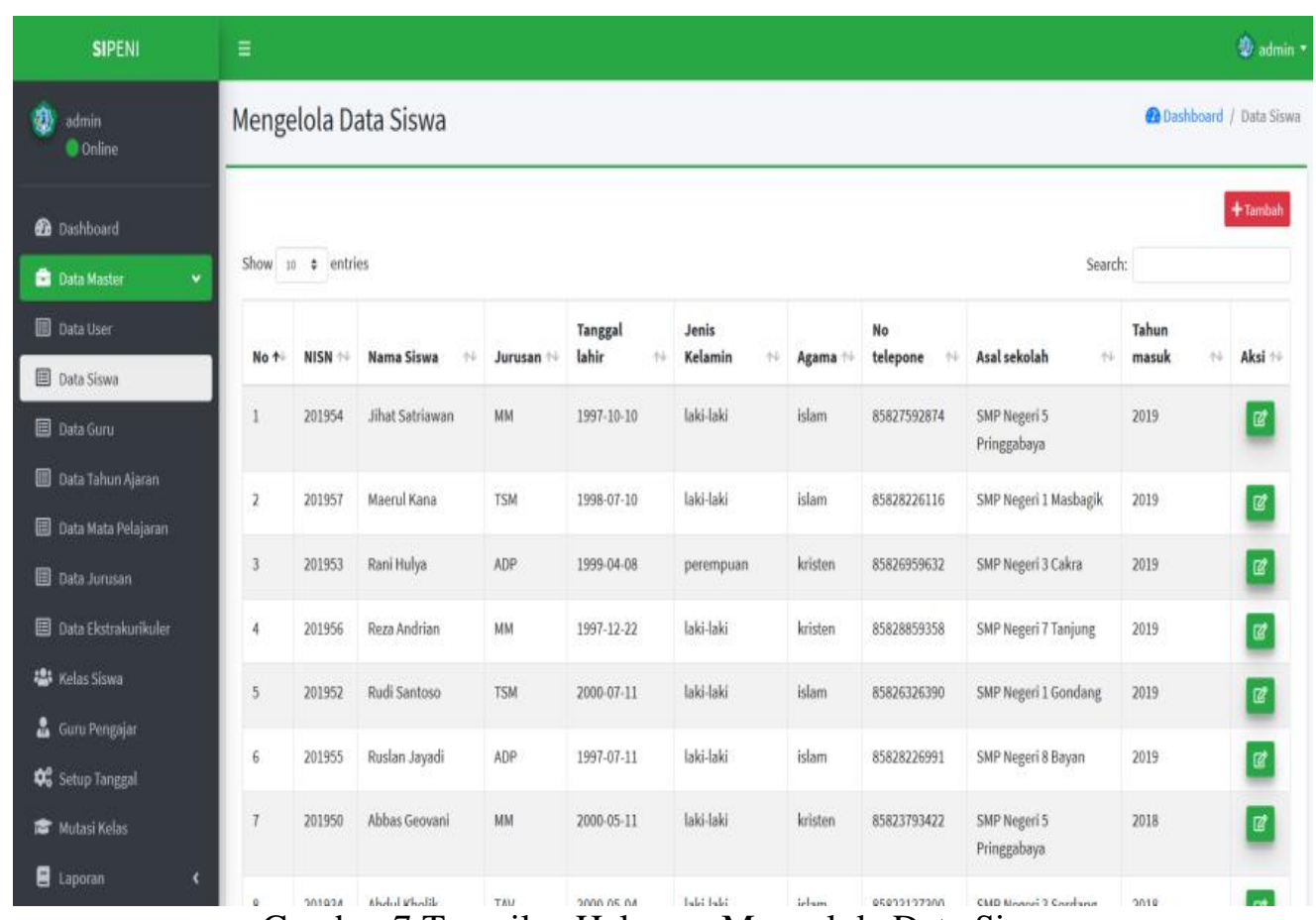

Gambar 7 Tampilan Halaman Mengelola Data Siswa

\section{KESIMPULAN}

Berdasarkan hasil dan pembahasan dari perancangan sistem pengolahan nilai berbasis web pada SMK Negeri 1 Kotaraja, maka kesimpulan yang didapat adalah sebagai berikut, Sistem ini dirancang mulai dari tahap mengidentifikasi masalah, kemudian mengumpulkan data dan mengelolanya, tahap berikutnya adalah menganalisis sistem dan merancang sistem, selanjutnya melakukan implementasi berdasarkan rancangan dari sistem yang dibuat, sistem ini dirancang dengan menggunakan bahasa pemrograman PHP dan MySQL sebagai databasenya, 
setelah sistem dibuat maka akan dilakukan pengujian sistem menggunakan blackbox testing. Sistem informasi pengolahan nilai rapor pada SMK Negeri 1 Kotaraja melingkupi: pengelolaan data user, data guru, data siswa, data kelas, data mata pelajaran, data jurusan, data kelas siswa, data tahun ajaran, data guru pengajar, data absensi, data ekstrakulikuler, setup tanggal input nilai, data nilai siswa dan fitur notifikasi. Pengujian sistem ini menggunakan blackbox testing dengan menjalankan atau mengeksekusi unit/modul, sehingga sesuai dengan rancangan dan berjalan dengan baik.

\section{SARAN}

Adapun saran dari penulis bagi penelitian selanjutnya dalam pengembangan bidang serupa, diharapkan dapat mengembangkan sistem informasi pengolahan nilai rapor ini dengan menambahkan fitur SMS Gateway untuk memberikan informasi jadwal input nilai kepada guru atau wali kelas. Pengembangan sistem informasi pengolahan nilai rapor ini diharapkan ditambahkan informasi data keuangan dan data wali murid yang bertujuan sebagai sarana informasi untuk wali murid dalam memantau perkembangan siswa.

\section{DAFTAR PUSTAKA}

[1] P. Sugiartawan, H. Rowa, and N. Hidayat, "Sistem Pendukung Keputusan Kenaikan Jabatan Menggunakan Metode Profile Matching", jsikti, vol. 1, no. 2, pp. 97-108, Dec. 2018.

[2] P.Sugiartawan,I.D.K.R. Rustina, R.W.S. Insani, "E-Government Media Informasi Alat Kelengkapan Dewan Provinsi Bali dan Media Diskusi Berbasis Website", J. Sist. Inf. dan Komput. Terap. Indones., vol. 2, no. 1, 2018.

[3] Rivai, D. A., "Pembangunan Sistem Informasi Pengolahan Data Nilai Siswa Berbasis Web Pada Sekolah Menengah Kejuruan (SMK) Miftahul Huda Ngadirojo”, Indonesian Journal on Networking and Security, 2013.

[4] Khoirudhin, A., \& Supriyono, H, "Aplikasi Pengolah Nilai Peserta Didik Pada SDIT Nur Hasan Senting Berbasis Desktop". Universitas Muhammadiyah Surakarta, 2018.

[5] Williams, B.K. and Sawyer, S.C., "Using Information Technology: A Practical Introduction to Computers \& Communications. (9th edition)", 2011.

[6] Newyork: McGraw-Hill Rosa \& Shalauhuddin, "Rekayasa Perangkat Lunak Terstruktur dan Berorientasi Objek", Bandung: Informatika Bandung, 2013.

[7] Pohan, Iskandar Husni, Kusnassriyanto, "Pengantar Perancangan Sistem", Jakarta: Erlangga, 2014.

[8] Buana, I Komang Setia, “Jago Pemrograman PHP”, Jakarta: Dunia Komputer, 2014.

[9] Kustiyahningsih, Y. \& Anamsia, D. R, "Pemrograman Basis Data Berbasis Web Menggunakan PHP \& MySql”, Yogyakarta: Graha Ilmu, 2011.

[10] Anhar, "PHP \& MySql Secara Otodidak", Jakarta: PT. Transmedia, 2010.

[11] Jogyanto, "Analisis dan Desain Sistem Informasi”, Edisi IV. Yogyakarta: Andi Offset, 2010.

[12] Rosa \& Shalauhuddin, "Rekayasa Perangkat Lunak Terstruktur dan Berorientasi Objek", Bandung: Informatika Bandung, 2013.

JSIKTI Vol. 2, No. 2, Desember 2019: $53-64$ 